\title{
Zarządzanie środowiskiem przyrodniczym w perspektywie public governance
}

\author{
Management of the Natural Environment in the Perspective of 'Public Governance'
}

\author{
Violetta Korporowicz-Żmichowska \\ Kolegium Ekonomiczno-Społeczne, Szkoła Główna Handlowa w Warszawie \\ ORCID: https://orcid.org/0000-0001-5582-1373• violetta.korporowicz@sgh.waw.pl \\ Zgłoszono: 28.12.2020; zrecenzowano: 22.02.2021; zaakceptowano do druku: 4.03.2021
}

Streszczenie: Zarządzenie środowiskiem przyrodniczym to działalność społeczeństwa, organizacji i pojedynczych osób. Jego celem jest ograniczanie niekorzystnych przemian w ekosystemach. Zarządzanie to jest procesem podejmowania i wprowadzania w życie decyzji dotyczących stanu środowiska. Jest ponadto praktyczną aktywnością mającą na celu utrzymanie i poprawę stanu środowiska przyrodniczego, które ulega degradacji w wyniku gospodarczej i bytowej działalności człowieka. Zarządzanie środowiskiem musi być spójne z polityką ekologiczną państwa, która jest celową oraz świadomą aktywnością władz państwowych. Zadaniem tej polityki jest zapewnienie bezpieczeństwa ekologicznego wszystkim obywatelom. Polityka ekologiczna polega na odgórnych decyzjach, planach, które są tworzone, aby osiągnąć poprawę dobra wspólnego, jakim jest środowisko. Poprawa ta dotyczy środowiska i jego jakości, które jest nie tylko dobrem prywatnym, lecz także dobrem publicznym, gdyż ma szczególnie ważne znaczenie dla funkcjonowania danego społeczeństwa. Część z problemów z zakresu ochrony środowiska może być rozwikłanych przez wdrażanie nowych rozwiązań organizacyjnych traktowanych jako proces społeczny. Mowa tu o idei public governance, która jest oddolnym podejściem do zarządzania w sferze publicznej, w tym również zarządzania środowiskiem. Public governance, czyli „partycypacyjne zarządzanie publiczne", to taki typ zarządzania, który cechuje się: zaangażowaniem interesariuszy, transparentnością decyzji, równością i brakiem wykluczenia poszczególnych członków czy grup społeczeństwa z możliwości decydowania o kształcie usług publicznych. Przykładem tu mogą być budżety obywatelskie, umożliwiające społecznościom lokalnym współdecydowanie 0 tym, jak będą realizowane inwestycje opłacane z części środków z budżetu samorządowego. Celem artykułu jest przedstawienie public governance - jednej z koncepcji zarządzania w sektorze publicznym - oraz próba odpowiedzi, czy koncepcja public governance może być wykorzystana w zarządzaniu środowiskiem przyrodniczym.

Słowa kluczowe: public governance, zarządzanie środowiskiem przyrodniczym, polityka ekologiczna

\begin{abstract}
Natural environmental management is the activity of society, organisations, and individuals, aimed at limiting unfavourable changes in eco-systems. This management is the process of making and implementing decisions, regarding the state of the environment. Moreover, it is a practical activity, aimed at maintaining and improving the condition of the natural environment, which is being degraded as a result of the economic and living activities of man. Environmental management must be consistent with the state's ecological policy, which is a deliberate and conscious set of activities of state authorities. The purpose behind this policy is to ensure ecological safety for all citizens. Environmental policy is about top-down decisions, plans that are created to improve the common good, which is the environment. This improvement concerns the environment and its quality, which is not only a 'private good'. It is also a public good, as it is of particular importance for the functioning of a given society. Some of the problems related to environmental protection, can be
\end{abstract}


solved by implementing new organisational solutions, treated as a social process. We are talking about the idea of 'public governance', which is a bottom-up approach to management in the public sphere, including environmental management. 'Public governance' or 'participatory public management' is a type of management that is characterised by: stakeholder involvement, transparency of decisions, equality, and the lack of exclusion of individual members or groups of society, from the possibility of deciding on the shape of public services. An example here may be civic budgets, which enable local communities to co-decide on the implementation of investments, financed from a part of the local government budget. The aim of the article, meanwhile, is to present 'public governance' - one of the concepts of management in the public sector, and to try to answer whether the concept of public governance can be used in managing the natural environment.

Keywords: public governance, management of the natural environment, ecological policy

\section{Wstęp}

Duże zainteresowanie tematyką stanu środowiska przyrodniczego, szczególnie od lat 70. ubiegłego wieku, wiąże się zarówno ze wzrostem jego znaczenia dla całej gospodarki, jak i wzrostem świadomości ekologicznej społeczeństwa. Do tego jednak czasu środowisko było nadmiernie eksploatowane, a jego degradację interpretowano $\mathrm{w}$ wąskiej, ilościowej perspektywie. Wraz z rozwojem nauki i społeczno-gospodarczym zauważono, że zasobów przyrody nie można tak łatwo odtworzyć, a dalszy rozwój gospodarki może być zahamowany. Pojawił się też aspekt jakościowy w sposobie rozumienia i metodach badania środowiska.

Nie istnieje wzrost, ani tym bardziej rozwój gospodarczy bez czystego środowiska, którego zapewnienie związane jest $\mathrm{z}$ realizacją zasad polityki ekologicznej (polityki ochrony środowiska). Taka polityka to kompleksowe wytyczanie sposobów i kierunków zabezpieczania przed rozwojem degradacji ekosystemów. Polityka państwa w aspekcie ochrony środowiska ma za zadanie wskazanie kierunków postępowania w celu zapewnienia wszystkim mieszkańcom wysokiej jakości środowiska przyrodniczego. Dlatego też środowisko i jego jakość zaczęto analizować na gruncie nauk społecznych przez pryzmat teorii dóbr publicznych. Z jednej strony jest to bowiem zasób, z którego korzystania nikogo nie można wykluczyć, z drugiej zaś jest to dobro prywatne. Dwoista rola znajduje wyjaśnienie w pracach teoretycznych (np. Blaug 1994, 600-601).
Kolejnym, nie mniej istotnym zagadnieniem środowiskowym jest realizacja polityki ekologicznej. Dotyczy ona zarządzania środowiskiem między innymi przez podmioty organizacyjne, szczególnie w gospodarce rynkowej, celem racjonalnego kształtowania zasobów przyrody, a w konsekwencji ograniczenia degradacji ekosystemów. Część problemów dotyczących ochrony środowiska może być rozwiązana przez wdrożenie nowych rozwiązań organizacyjnych, rozumianych jako proces społeczny. Mowa tu o nowym podejściu do zarządzania w sferze publicznej, tzn. public governance, jako demokratycznego, oddolnego podejścia do zarządzania. Przykładem takiego podejścia są budżety obywatelskie (partycypacyjne), których celem jest zwiększenie zaangażowania oraz wpływu mieszkańców na decyzje podejmowane przez lokalne władze, oparte na poszanowaniu potrzeb i opinii mieszkańców. Mieszkańcy są włączani do decydowania o kształcie części lokalnego budżetu w wyniku konsultacji społecznych (Service Agency Communities in One World 2013).

Celem artykułu jest przedstawienie public governance - jednej z koncepcji zarządzania w sektorze publicznym - oraz próba odpowiedzi, czy koncepcja public governance może być wykorzystana w zarządzaniu środowiskiem przyrodniczym.

\section{Polityka ekologiczna i jej racjonalność w zarządzaniu środ owiskiem}

Człowiek wywiera znaczący wpływ na środowisko przyrodnicze. Korzystanie z dóbr 
przyrody oraz przestrzeni wprowadza istotne zmiany, których skutki są widoczne nie tylko obecnie, lecz także w przyszłości będą jeszcze bardziej zauważalne. Wszystko to związane jest $\mathrm{z}$ z intensywnymi sposobami gospodarowania zasobami przyrody i nadmiernym dążeniem społeczeństw do wzrostu zamożności, który następuję wraz z zachodzącymi procesami cywilizacyjnymi. Często w tych działaniach brakuje solidarności z obecnymi pokoleniami, jak i myślenia o przyszłych generacjach.

Kierunkami wytyczania rozwoju i kształtowania przemian w ekosystemach zajmuje się polityka ekologiczna. Jest to działalność państwa rozumiana jako społeczny proces związany z projektowaniem i wdrażaniem działań pozytywnie wpływających na kształt środowiska przyrodniczego (Prandecka 1991, 19-20), oraz kompleksowe wytyczanie kierunków rozwoju środowiska przyrodniczego. Polityka ekologiczna odnosi się do odgórnych planów władzy publicznej podejmowanych w celu osiągnięcia konkretnych celów środowiskowych (Poskrobko 2020, 6). Zarazem jest to celowa oraz świadoma aktywność władzy publicznej polegająca na umiejętnym korzystaniu z zasobów i walorów środowiska przyrodniczego, ochronie i kształtowaniu ekosystemów lub wybranych elementów biosfery.

Polityka ta ma za zadanie zapewnienie bezpieczeństwa ekologicznego oraz wysokiej jakości życia dla wszystkich mieszkańców. Dotyczy ona kształtu, zakresu i sposobu stosowania teorii nauk, w tym o środowisku, na grunt społeczny. Jedna z teorii stwierdza, że kreują ją grupy społeczne, które wpływają na sytuację instytucji tworzących system ochrony środowiska. Uogólniając, polityka ekologiczna dotyczy odgórnych decyzji, planów władzy publicznej, które podejmowane są, aby osiągnąć poprawę dobra, jakim jest środowisko.

Celowość działań w obszarze polityki ekologicznej oznacza też wpływ na sposób rozdzielania zasobów przyrody pomiędzy rywalizujące między sobą grupy społeczne, po to aby skutecznie wykorzystywać zasoby i walory środowiska przyrodniczego. Zasadność tej polityki, zgodnie z zasadą zrównoważonego rozwoju oraz solidarności z kolejnymi pokoleniami, odnosi się do decyzji i wskazywania kierunków działań, które podejmowane są, aby osiągnąć konkretne cele ochrony środowiska w społeczeństwie (Konstytucja Rzeczypospolitej Polskiej rodz. I, art. 5). Ponadto wysoki „[...] poziom ochrony środowiska i poprawa jego jakości muszą być zintegrowane z politykami Unii i zapewnione zgodnie z zasadą zrównoważonego rozwoju." (Karta praw podstawowych Unii Europejskiej 2015, art. 37). Jako uzupełnienie tej myśli można dodać, że polityka ekologiczna oznacza też włączenie aspektów środowiskowych do polityk sektorowych, czyli wyznaczanie w kompleksowy sposób kierunków rozwoju, w tym uwzględnianie poprawy stanu środowiska, na równi z celami gospodarczymi i społecznymi (Rada Ministrów 2019).

$\mathrm{Na}$ tym tle uzasadniona jest interwencja władzy państwowej w celu prawidłowego wykorzystania i kształtowania środowiska przyrodniczego, na które negatywnie wpływa działalność gospodarcza człowieka. Interwencja ta dotyczy środowiska i jego jakości, którego nie można traktować tylko jako dobra prywatnego (Varian 2002, 643). Jest to również dobro publiczne, gdyż ma ono szczególnie ważne znaczenie dla funkcjonowania danego społeczeństwa, jako że jest dobrem użytkowanym i specyficznie „konsumowanym” wspólnie przez wszystkich członków społeczeństwa (Desai 2003, 6). Ponadto są to dobra, które „[....]moga być dostarczane wszystkim [...] przy koszcie nie większym od koniecznego do dostarczania ich jednej osobie. Korzyści wynikające z konsumpcji takich dóbr są niepodzielne i nikogo nie można wyłączyć z korzystania z nich." (Samuelson i Nordhaus 2012, 509). Konsumpcja dóbr publicznych koniecznie musi być równa (egalitarna), tzn. jeżeli więcej takich dóbr jest dla jednego gospodarstwa domowego, tyle samo będzie dla każdego innego. 
Środowisko (np. krajobraz, las czy powietrze) i jego ochrona nie zawsze są dostarczane odbiorcom poprzez rynek, ponieważ przeciętny uczestnik rynku raczej nie byłby skłonny do takiego zakupu (Pniewski i Bartoszewicz 2008, 49-52). Korzyści płynące z użytkowania, takie jak np. likwidacja nielegalnych śmietników czy oczyszczanie zanieczyszczonych terenów sprzyjających powstawaniu chorób zakaźnych, dane są każdemu, bez względu na to, czy za nie zapłacił, czy też nie. Dlatego zakłada się, że państwo musi przez wskazania zawarte w polityce ekologicznej ingerować w dystrybucję dobra publicznego. Są to wybory o charakterze ponadindywidualnym, a dokonywane w celu rozwiązywania licznych problemów społecznych, politycznych, gospodarczych oraz środowiskowych, gdyż bez czystego środowiska nie może być ani rozwoju, ani postępu ekonomicznego i społecznego. Uznanie środowiska jako dobra publicznego, a nie tylko prywatnego, ma zatem swoje istotne konsekwencje społeczne, które potwierdzają, że ochrona środowiska, jako element polityki ekologicznej, powinna być dostarczana również przez państwo, a nie tylko za pośrednictwem rynku.

Zauważalne jest, że decyzje w gospodarce rynkowej z zakresu sposobu produkcji i konsumpcji powinny mieć określone ramy czasowe i organizacyjne, ponieważ podejmowane są przez niezależne podmioty. Podmioty te kierują się własnym interesem i postępują zgodnie z zasadami własnej racjonalności gospodarowania (tzn. maksymalizują efekty przy założonym poziomie nakładów, lub minimalizują nakłady przy założonym poziomie efektów). Siłą napędzającą rozwój w tego typu gospodarce jest mechanizm rynkowy, czyli wzajemne oddziaływanie elementów składowych rynku, przede wszystkim popytu, podaży i cen. Natomiast mechanizm rynkowy w przypadku środowiska przyrodniczego i jego ochrony, które są dobrami publicznymi, nie jest w stanie w pełni skłonić konsumentów do ujawnienia wszystkich preferencji. Również podaż dóbr publicznych nie jest związana i nie może być określona tylko za pomocą mechanizmów rynkowych, ale też przez decyzje zarządcze instytucji państwowych. $Z$ reguły podmiot gospodarujący nie będzie chętnie przyczyniał się do inwestowania w ochronę środowiska, ponieważ popyt na dobra dotyczące takiej ochrony kształtuje się często niezależnie od decyzji związanych z rachunkiem ekonomicznym. Decyzje te dotyczą raczej stosownych przepisów.

Niepodzielność środowiska i jego ochrony powoduje zatem, że o ich dystrybucji często decydować musi państwo, posługując się oraz wspierając na przemian wynikami głosowania, kompromisami politycznymi oraz - rzadziej, ale też - rachunkiem ekonomicznym. Oznacza to, że niezależnie od wymiaru ekonomicznego trzeba brać pod uwagę to, że dobra publiczne muszą być równo dostarczane obywatelom danego kraju, stale i bez przerwy. Dlatego obowiązkiem każdego państwa jest dbanie o stan środowiska (jako wyraz realizacji założeń polityki ekologicznej), a to wymaga wysiłku ekonomicznego i legislacyjnego. W praktyce społecznej istnieje oczywiście wiele odstępstw od tego, gdyż ustalenie granic dla odpowiedzialności indywidualnej i społecznej za stan środowiska jest zadaniem bardzo trudnym ${ }^{1}$.

Wdrażanie zasad polityki ekologicznej realizowane jest poprzez zarządzanie środowiskiem przyrodniczym (zarządzanie ochroną środowiska). Zarządzanie to jest procesem podejmowania i wprowadzania w życie decyzji dotyczących stanu środowiska, np. przez podmioty gospodarcze. Jest też celowym praktycznym działaniem zajmującym

${ }^{1}$ W przypadku środowiska i jego jakości pojawia się aspekt efektów zewnętrznych, które występują wtedy, gdy jednostki (zakłady, osoby prywatne) wpływają na poziom dobrobytu innych jednostek, mimo że nie nastąpiła żadna transakcja rynkowa. Brak transakcji rynkowej oznacza, że jednostki nie ponoszą pełnych kosztów swej działalności. Są one przeniesione na inne jednostki, które nie są uczestnikami rynku. Zatem efekt zewnętrzny występuje wtedy, gdy produkcji lub konsumpcji towarzyszą koszty lub korzyści, które dotykają osób trzecich, które nie są ani producentami, ani konsumentami danego dobra. 
się utrzymaniem i poprawą stanu środowiska przyrodniczego, który to stan jest ograniczany w wyniku gospodarczej i bytowej aktywności człowieka (Delmas, Toffee. 2004, 209-222).

Konsekwencją takiego rozumowania są działania z zakresu zarządzania ochroną środowiska odnoszące się do racjonalnego jego kształtowania, które podejmowane są w celu osiągnięcia założonych zadań środowiskowych. Działania te nastawione są na dążenie do osiągnięcia określonego celu. Jest to zestaw sformułowanych założeń lub przesłanek dotyczących motywacji, podejmowania decyzji w zakresie ochrony środowiska. Używa się tutaj pojęcia racjonalności środowiskowej, aby powiązać zarządzanie środowiskiem z maksymalizowaniem bogactwa społeczeństwa. Dzieje się tak, aby osiągnąć korzyść najlepszą z możliwych, traktowaną jako korzyść utraconą w wyniku dokonanego wyboru (mowa o koszcie alternatywnym). Inaczej mówiąc, koszty alternatywne stanowią miarę wartości utraconych korzyści w związku z wykorzystaniem dostępnych zasobów na inny cel. Trzeba dodać, że część badaczy uważa, że racjonalność w zakresie ochrony środowiska nie jest wyłącznie problemem ekonomicznym. Nie jest to zarzut, ale raczej efekt dyskusji metodologicznej, w której przedstawiciele innych dyscyplin uważają, że w kategorii racjonalności należy upatrywać nie tylko aspektów środowiskowych i ekonomicznych. Uogólniając zagadnienie racjonalności w zarządzaniu środowiskiem, to jej cel będzie osiągnięty, jeżeli decyzje będą przemyślane i zostaną podjęte świadomie z uwzględnieniem kosztów oraz korzyści, jak i w odniesieniu do możliwości podjęcia działań alternatywnych (McKenzie 2010, 1-4).

Uzupełniając celowe podejście do zarządzania środowiskiem o wątek ekonomiczny, należy podkreślić, że jego podstawowym celem powinna być poprawa stanu środowiska, ale przy uwzględnieniu kosztów niezbędnych do zrealizowania. Dodając ponadto aspekt ekonomiczny, istotne jest, aby cel ten był osiągany efektywnie i skutecz$n^{n} e^{2}$. Efektywność jest o tyle ważna, gdyż wydatki związane z ochroną środowiska są wysokie, a tzw. potencjalny zwrot kosztów należy rozpatrywać jedynie w perspektywie długoterminowej. To ogranicza możliwość szybkiej oceny prawidłowości podjętych decyzji w tym obszarze. Pomimo pewnych trudności w gospodarowaniu środowiskiem przyrodniczym, kwestia ta powinna być priorytetem w zarządzaniu środowiskiem, ponieważ bez czystego środowiska nie ma ani zdrowego społeczeństwa, ani rozwoju gospodarki ${ }^{3}$.

Kolejnym aspektem zarządzania środowiskiem jest odniesienie do podmiotów organizacyjnych. Jego istotną część stanowią właśnie aspekty środowiskowe zintegrowane z ogólnym systemem zarządzania wraz $\mathrm{z}$ procesem produkcyjnym, $\mathrm{np}$. $\mathrm{w}$ przedsiębiorstwie lub gminie. Sterowanie to dotyczy planowania, opracowywania, wdrażania, kontroli w sposób uwzględniający zagadnienia środowiska w jednostce organizacyjnej (Nierzwicki 20o6, 12-13). Ma też wypracowany zestaw specjalistycznych narzędzi, które umożliwiają wdrażanie polityki ekologicznej w podmiotach organizacyjnych (Komisja Europejska 2019).

Wśród narzędzi zarządzania środowiskiem najistotniejszą rolę odgrywają dwa standardy: ISO (International Organization for Standarization) 14001 oraz EMAS (Eco-Management and Audit Scheme). Dzięki

2 Relacje między społeczeństwem a środowiskiem sprawiają, że liczne nauki wypowiadają się na temat jego kształtowania. Naukami tymi są np.: geografia, geologia, geofizyka, klimatologia, ekologia, nauki medyczne, antropologia, ekonomia oraz socjologia. Liczba dziedzin poszerzających swe analizy o aspekt przyrodniczy stale wzrasta, a z niektórych nauk, takich jak ekonometria i statystyka, wykorzystuje się metody i narzędzia do prognozowania przemian środowiskowych.

3 W polskiej literaturze przedmiotu występuje również pojęcie „zarządzania środowiskowego", które obejmuje gospodarowanie środowiskiem, ale z uwzględnieniem struktury podmiotu organizacyjnego. Zarządzanie to $\mathrm{w}$ takim ujęciu przypisane jest do jednostki (np. przedsiębiorstwa, gminy). 
ich zastosowaniu jednostki mogą obniżyć koszty za pomocą usprawnionych procesów gospodarczych, a także zminimalizować ryzyko wystąpienia niekorzystnych zmian w środowisku. Przyczyny wdrażania systemu zarządzania środowiskiem $w$ podmiotach to między innymi: zwiększenie świadomości kadry zarządczej, akcjonariuszy, pracowników oraz klientów czy chęć poprawy wizerunku instytucji, gdyż troska o środowisko może doprowadzić do umocnienia pozycji podmiotu na rynku (Nahotko 2020, 89-90).

Podsumowując, można powiedzieć, że zarządzanie środowiskiem jest to wieloaspektowa działalność władz publicznych, podmiotów organizacyjnych oraz osób prywatnych mająca na celu: projektowanie, wdrażanie, koordynowanie gospodarczych i bytowych procesów korzystania ze środowiska. Zarządzanie to prowadzić powinno do minimalizowania skutków negatywnego oddziaływania człowieka na środowisko oraz wskazywać też na potencjalne kierunki postępowania (Hammer 2001, 1-2).

\section{Public governance w zarządzaniu środowiskiem przyrodniczym}

Public governance czyli partycypacyjne zarządzanie publiczne, w którym sektor publiczny pozostaje w pozytywnych relacjach i oddziaływaniu na siebie członków społeczeństwa (Lasswell and Lerner 1965, 31). Jest to „[...] sposób zarządzania [...] oparty na udziale wszystkich członków organizacji i nakierowany na osiągnięcie długotrwałego sukcesu dzięki [...] korzyściom dla wszystkich członków organizacji i dla społeczeństwa." (Hamrol 2005, 67). Ten model zarządzania instytucjami publicznymi jest odmienny od zarządzania opartego na hierarchicznej strukturze organów władzy oraz ich wąskiej specjalizacji (Koch and Dixon 2007)

Wnikliwsze spojrzenie na pojęcie governance rozumiane jako współrządzenie, wskazuje na potrzebę poszukiwań działań zbiorowych w systemie produkcji i alokacji dóbr (Szczupaczyński 2017, 81). Podejście to możemy rozumieć jako odpowiedzialność społeczności za efekty zaspokojenia istotnych potrzeb społecznych, które są finansowane z reguły ze środków publicznych (Frączkiewicz-Wronka i in. 2015). Taki typ rządzenia cechuje: transparentność decyzji, zaangażowanie interesariuszy, równość, brak wykluczenia oraz dyskryminacji poszczególnych członków czy grup społeczeństwa w dostępie do informacji oraz jawność w korzystaniu z usług publicznych (Hausner 2019, 94).

Co istotne dla rozważań, to w terminie public governance mieści się wymiar abstrakcyjny i aplikacyjny. Wymiar abstrakcyjny governance można określić jako teorię kierowania, na gruncie której badane są między innymi rzeczywiste zjawiska społeczne, np. potrzeby ludności. Różne potrzeby i ich sposoby zaspokojenia wpływają na zróżnicowane profile badań, dzięki którym można opisywać przemiany. Zawarte są w nich nie tylko pytania, lecz także wskazania potencjalnych kierunków postępowania. Odnosząc governance do podejmowania konkretnych działań (wymiar aplikacyjny), dotyczą one umiejętności członków społeczności przez między innymi: artykułowanie własnych potrzeb, np. w zakresie ochrony i kształtowania przyrody (Osborne 2006, 377-387).

Z punktu widzenia zakresu tematycznego to public governance możemy też rozumieć jako „sztukę” kierowania, która dotyczy jednocześnie stałego podnoszenia jakości z równoczesnym określaniem rzeczywistych zjawisk społecznych z uwzględnieniem udziału społeczeństwa (Szczupaczyński 2017, 82-83). „Sztuka” ta rozwija się przez odwołanie do istniejących realnych, nienarzuconych potrzeb. W takim podejściu szczególnie istotne jest to, żeby można było prowadzić dyskurs publiczny. Odbywa się on na bazie wymiany poglądów w nowoczesnym, demokratycznym społeczeństwie. Governance rozumiane jest też jako wymóg sprawnego zarządzania przez permanentne, nastawione na rozwój, kreatywne rozstrzyganie o kluczowych trudnościach organizacji (Korporowicz 2017, 163). Część z problemów 
społecznych może być rozwiązanych przez wdrażanie właśnie idei public governance jako nowych rozwiązań organizacyjnych z wykorzystaniem procesu partycypacyjnego. Mowa tu o oddolnym podejściu do zarządzania, w tym również zarządzania środowiskiem ${ }^{4}$.

W public governance $\mathrm{w}$ odniesieniu do środowiska przyrodniczego ujawniają się nowe formy i zasady umowy obywatelskiej, legitymizacji podmiotów sektora publicznego, gdzie eksponowana jest rosnąca współodpowiedzialność i współzależność otoczenia sieciowego (Pabiś 2017, 15). Są to następujące zasady, np.:

- zbadanie i określenie lokalnych potrzeb środowiskowych jako swoista analiza otoczenia. Dzieje się tak przede wszystkim dlatego, że społeczności najlepiej znają swoje potrzeby środowiskowe;

- ciągłe poszukiwanie nowoczesnych kierunków postępowania, w których istotne jest nastawienie na rozwój przejawiające się szukaniem nietypowych rozwiązań. Taki typ postępowania związany jest z ciągłymi zmianami wynikającymi ze stale rosnących potrzeb dotyczących jakości środowiska i oczekiwań członków społeczności i ich interesariuszy;

- partycypacyjne uczestnictwo licznych członków społeczeństwa na rzecz poprawy stanu środowiska.

Wdrażanie tych zasad w obszarze ochrony środowiska przyrodniczego jest możliwe dzięki demokratyzacji życia społecznego, która ułatwia przekazanie przez szczebel wyższy do niższego licznych uprawnień o charakterze wykonawczym, co z kolei

4 Public governance jako model zarządzania $\mathrm{w}$ sferze publicznej wykształcił się w odpowiedzi na bariery organizacyjne związane $\mathrm{z}$ zarządzaniem typu new public management (NPM). W new public management - popularnym kierunku zarządzania szczególnie w latach 80. i 90. XX w., przeprowadzano reformy administracyjne dzięki zastosowaniu metod i technik zarządzania wypracowanych w sektorze prywatnym. Miały one na celu poprawę efektywności i jakości zarządzania. przekłada się na poszukiwanie nowych form komunikacji społecznej. W tym nurcie zarządzania kładzie się też silny nacisk zarówno na ekonomiczne aspekty wydatkowania środków publicznych, jak i na poprawę efektywności, jakości i skuteczności działań publicznych realizowanych przez podmioty na rzecz ochrony środowiska.

Na tym tle w zarządzaniu typu governance w ochronie środowiska, z czym należy się zgodzić, istotna jest orientacja na rozwój, a nie tylko na osiąganie wyników. Jest to przejście od menadżerskiego, parametrycznego zarządzania środowiskiem w kierunku modelu kładącego dużo większy nacisk na personalną, indywidualną odpowiedzialność społeczeństw (Lapuente and Van de Walle 2020, 461-470). Jest to odejście od schematycznego sposobu zarządzania w kierunku stworzenia bardziej elastycznych warunków zatrudnienia, pracy w organizacji. Ewolucja ta dotyczy poszukiwania nowych, innowacyjnych podstaw zarządzania, w których można zastosować mechanizmy oddolne, tzn. włączanie społeczeństwa do:

- decydowania o rozwoju, np. otoczenia przyrodniczego,

- określania potrzeb środowiskowych i metod ich zaspokojenia,

- finalnej kontroli realizacji zaspokojenia potrzeb środowiskowych.

Podsumowując, to trafna diagnoza potrzeb w zarządzaniu środowiskiem i umiejętne podejmowanie decyzji w celu ich zaspokojenia oraz wspólne dzielenie się odpowiedzialnością, które pojawiają się w teorii governance, mogą być podstawą do osiągania korzyści środowiskowych. Zastosowanie tych kierunków działań jest przydatne właśnie w opracowywanych strategiach środowiskowych wykorzystywanych przez np. samorządy terytorialne.

Przykładem wykorzystania podejścia do zarządzania typu governance w zarządzaniu ochroną środowiska może być idea budżetów obywatelskich (partycypacyjnych), Jest to wynik procesu dyskusji, a następnie podejmowania decyzji co do planów gospodarczych wraz z wydatkowaniem na 
ich realizację części środków z budżetu samorządowego. Proces ten umożliwia przekazanie społecznościom lokalnym przez władze publiczne uprawnień o charakterze wykonawczym. Do tego procesu włączani są interesariusze, w tym przypadku właśnie mieszkańcy gmin i miast, którzy współdecydują o tym, jakie będą realizowane inwestycje z części środków z budżetu samorządowego.

Budżety obywatelskie zapewniają przestrzeń do dyskusji, czyli takiej formy wymiany opinii i poglądów, gdzie mieszkańcy mają takie same prawa co władze miasta czy gminy, urzędnicy, eksperci (Kraszewski i Mojkowski 2014, 3-4). Budżety te najczęściej są tworzone w wyniku wykorzystania takich mechanizmów, jak: poznanie priorytetów inwestycyjnych, wybór działań z budżetów reprezentujących lokalne społeczności, wsparcie infrastrukturalne ze strony urzędów miast i gmin. Kolejno istotna jest implementacja pomysłów mających bezpośredni wpływ na jakość życia oraz poczucie odpowiedzialności i solidarności mieszkańców „małych ojczyzn”. Mechanizmy te sprawiają, że budżety publiczne są bardziej sprawiedliwe i efektywniej zagospodarowywane, a to buduje ponadto silniejsze więzi społeczne na szczeblu lokalnym.

Za przewagą zarządzania środowiskiem typu governance w postaci realizacji projektów obywatelskich w stosunku do innych typów zarządzania przemawia fakt, że wykorzystywane są siły oddolne. Wspierają one działania społeczności lokalnych na rzecz ich rozwoju. To te społeczności najlepiej rozumieją potrzeby, w tym środowiskowe, gdyż bezpośrednio korzystają z tych potencjałów.

O skuteczności zainteresowania współdecydowaniem mieszkańców stanem środowiska przyrodniczego świadczą złożone wnioski oraz wyniki głosowania na projekty obywatelskie. Przykładem mogą być zgłoszenia w ramach budżetów partycypacyjnych w Warszawie w 2019 r. Mieszkańcy stolicy zgłosili łącznie 2242 propozycji, w tym 199 ogólnomiejskich i 2043 dzielnicowe.
Większość wniosków dotyczyła właśnie ochrony środowiska przyrodniczego w postaci: rozbudowy parków i terenów zielonych, budowy boisk oraz budowy tężni solankowych czy zbudowania butelkomatów, tzn. urządzeń skupujących puste opakowanie szklane bądź plastikowe. Również w innych miastach Polski odbywają się podobne wybory w ramach funduszy partycypacyjnych, np. w Białymstoku, gdzie mieszkańcy już od stycznia 2020 r. mogą korzystać z pierwszych butelkomatów zakupionych właśnie dzięki tego typu inicjatywom. Ponadto w Białymstoku działania te przyniosły dodatkowe korzyści - za pieniądze uzyskane ze sprzedaży butelek zostały kupione, a następnie posadzone drzewa.

\section{Podsumowanie}

Gospodarując posiadanym środowiskiem przyrodniczym, rozumianym jako bogactwo naturalne, trzeba brać pod uwagę aspekt ilościowy i jakościowy rozwoju, w którym ważna jest solidarność z obecnymi i przyszłymi pokoleniami. Aby to zapewnić, należy rozpoznać, a następnie prognozować stale zachodzace przemiany w ekosystemach. Na podstawie takich prognoz można podejmować decyzje odnośnie do kierunków rozwoju środowiska przyrodniczego. Kierunki te związane są z uwarunkowaniami społecznymi, ekonomicznymi i możliwościami poprawy stanu środowiska rozumianymi jako wyraz realizacji zadań polityki ekologicznej państwa. Zważywszy na fakt, że środowisko przyrodnicze jest dobrem publicznym, działania w tym aspekcie powinno też podejmować państwo, które opracowuje politykę ekologiczną.

Polityka ekologiczna dotyczy odgórnych decyzji, planów i kierunków działań, które mają być podejmowane, aby osiągnąć konkretne cele środowiskowe. Ponadto polityka ta zajmuje się wytyczaniem potencjalnych możliwości kształtowania i ochrony ładu przyrodniczego jako dobra wspólnego. Można więc uznać, że polityka ekologiczna to świadoma i celowa działalność państwa w zakresie wytyczania kierunków 
gospodarowania środowiskiem, czyli użytkowania jego zasobów i walorów. Są one podejmowane, aby osiągnąć konkretne cele środowiskowe w społeczeństwie. Co istotne, polityka ta powinna być zgodna z zasadą zrównoważonego rozwoju i troską o możliwości rozwoju kolejnych pokoleń.

Politykę ekologiczną należy odróżnić od zarządzania środowiskiem, które jest realizacją, czyli wdrażaniem do praktyki społecznej założeń tej polityki. Zarządzenie środowiskiem to działalność, którego celem jest ograniczanie niekorzystnych przemian w ekosystemach. Obie te aktywności (polityka ekologiczna i zarządzanie środowiskiem) są względem siebie komplementarne, gdyż bez wytyczenia kierunków postępowania nie ma prawidłowej praktyki związanej z ochroną ekosystemów.

W obszarze ochrony środowiska stosunkowo nowym podejściem do zarządzania jest public governance. Istotnym aspektem tego podejścia jest zmiana sposobu zarządzania, która charakteryzuje społeczeństwa demokratyczne, jako konsekwencja ewolucyjnego przejścia od struktur centralistycznych do struktur sieciowych zaprojektowanych do realizacji zadań o charakterze publicznym.

Governance w zarządzaniu środowiskiem dotyczy podejmowania konkretnych działań wypracowanych w wyniku partycypacji społecznej, przez którą należy rozumieć metodę zarządzania opartą na udziale członków organizacji. Wtedy też środowisko ma szansę na poprawę stanu, gdyż istotna jest w tych działaniach współodpowiedzialność, współdecydowanie, solidarność i kontrola społeczna.

Ilustracją zarządzania typu governance w ochronie środowiska mogą być budżety obywatelskie, w których mieszkańcy gmin i miast cieszą się tymi samymi prawami do współdecydowania i kontroli, co decydenci życia publicznego. Realnie wpływają na to, jakie inwestycje będą realizowane, opłacane z części środków z budżetu samorządowego. Praktyka społeczna pokazuje, że mieszkańcy chętnie włączają się i decydują o kierunkach finansowania potrzeb lokalnych, w tym działań w zakresie kształtowania i ochrony środowiska. Wydaje się, że takie podejście do zarządzania może przynieść pozytywne efekty środowiskowe.

Warto też stale mieć na uwadze, że środowisko przyrodnicze Ziemi jest dobrem ogólnoludzkim, które należy chronić, dbać o nie, a także rozsądnie korzystać z dostępnych zasobów, gdyż środowisko przetrwa bez człowieka, ale człowiek bez środowiska nie może żyć.

\section{Bibliografia}

Blaug, Mark. 1994. Teoria ekonomii. Ujęcie retrospektywne. Warszawa: Wydawnictwo Naukowe PWN.

Delmas, Magali, and Michael W. Toffee. 2004.

"Stakeholders and environmental management practices: an institutional framework." Business Strategy and the Environment 13(4): 209- 222.

Desai, Meghnad. 2003. Public Goods: Historical Perspective. Oxford: Oxford University Press. https:// doi.org/10.1093/0195157400.001.0001.

Frączkiewicz-Wronka, Aldona, Martyna Wronka-Pośpiech, i Alfonso L. Montero. 2015. „Innowacje - przesłanki wyłaniania się nowego paradygmatu polityki społecznej.” W Innowacyjna polityka społeczna, red. Mirosław Grewiński i Arkadiusz Karwacki, 27-43. Warszawa: Wyższa Szkoła Pedagogiczna im. J. Korczaka w Warszawie. Hammer, Michael J. 2001. The agenda, what every business must do to dominate the decade. New York: Crown Business.

Hamrol, Adam. 2005. Zarzadzanie jakościa z przyktadami. Warszawa: Wydawnictwo Naukowe PWN.

Hausner, Jerzy. 2019. Społeczna czasoprzestrzeń gospodarowaniu. W kierunku ekonomii wartości. Kraków: Wydawnictwo Nieoczywiste.

Karta Praw Podstawowych Unii Europejskiej. Dziennik Urzędowy Unii Europejskiej 202/389 z 7.06.2016 r. https://eur-lex.europa.eu/legal-content/PL/TXT/PDF/?uri=CELEX:12016P/ TXT\&from $=\mathrm{DE}$.

Koch, Rainer, and John Dixon (eds.). 2007. Public Governance and Leadership: Political and Managerial Problems in Making Public Governance Changes the Driver for Re-Constituting Leadership. 
Frankfurt/Main: Deutscher Universitätsverlag. https://doi.org/10.1007/978-3-8350-9100-9.

Komisja Europejska. 2019. Unijny przeglad wdrażania polityki ochrony środowiska z 2019 r. Sprawozdanie krajowe - POLSKA. Bruksela: Komisja Europejska. Dostęp 14.02.2021. https://ec.europa.eu/ environment/eir/pdf/report_pl_pl.pdf.

Konstytucja Rzeczypospolitej Polskiej z dnia 2 kwietnia 1997 r. uchwalona przez Zgromadzenie Narodowe w dniu 2 kwietnia 1997 r. (t.j. Dz.U. 1997 nr 78 poz. 483). http://isap.sejm.gov.pl/isap.nsf/download.xsp/WDU19970780483/U/D19970483Lj.pdf.

Korporowicz, Violetta. 2017. „Zarządzanie progresywne w zdrowiu publicznym jako przejaw public governance." W Nowe idee zarzadzania publicznego. Wyzwania i dylematy, red. Ewa M. Marciniak, i Jerzy Szczupaczyński, 157-174. Warszawa: INP Wydział Nauk Politycznych i Studiów Międzynarodowych UW.

Kraszewski, Dariusz, i Karol Mojkowski. 2014. Budzet obywatelski w Polsce. Warszawa: Fundacja im. Stefana Batorego. Dostęp 21.12.2020. https://partycypacjaobywatelska.pl/wp-content/ uploads/2015/07/Budzet-obywatelski-w-PolsceD.-Kraszewski-K.-Mojkowski.pdf.

Lapuente Victor, and Steven Van de Walle. 2020. "The effects of new public management on the quality of public services." Governance 33(3): 1-15. https://doi.org/10.1111/gove.12502.

Lasswell, Harold, and Daniel Lerner. 1965. World revolutionary elites. Studies in coercive ideological movements. Cambridge: M.I.T. Press.

McKenzie, Richard B. 2010. Predictably rational. Berlin: Springer.

Nahotko, Sławomir. 2020. Podstawy zarzadzania ekologicznego przedsiębiorstwem. Bydgoszcz: Oficyna Wydawnicza Ośrodka Postępu Organizacyjnego Sp. z o.o.

Nierzwicki, Witold. 2006. Zarzadzanie środowiskowe. Warszawa: PWE.

Osborne, Stephen P. 2006. "The new public governance.” Public Management Review 1: 377-387.

Pabiś, Łukasz. 2017. „Zrównoważony rozwój w kontekście nowych koncepcji zarządzania publicznego: new public management i public governance (nowego zarządzania publicznego i zarządzania partycypacyjnego." Zeszyty Naukowe Politechniki Częstochowskiej Zarzaddzanie 25(2): 7-22. https:// doi.org/10.17512/znpcz.2017.1.2.01.

Pniewski, Krzysztof, i Bohdan Bartoszewicz. 2008. „Kreowanie wartości jako cel nadrzędny.” W Value based management. Koncepcje, narzędzia, przykłady, red. Andrzej Szablewski, Krzysztof Pniewski, Bohdan Bartoszewicz, 49-60. Warszawa: Deloitte, Poltext.

Poskrobko, Tomasz. 2020. Polityka ochrony środowiska. Dostęp 14.02.2021. https://www.weif.uwb. edu.pl/uploads/tiny//Tomasz\%20Poskrobko\%20 -\%20pliki/Ekonomia\%20\%C5\%9Brodowiska/Polityka\%20ekologiczna.pdf.

Prandecka, Barbara. 1991. Nauki ekonomiczne a środowisko przyrodnicze. Warszawa: Państwowe Wydawnictwo Ekonomiczne.

Rada Ministrów. 2019. Polityka ekologiczna państwa 2030 - strategia rozwoju w obszarze środowiska i gospodarki wodnej. Dostęp 14.02.2021. https://bip. mos.gov.pl/fileadmin/user_upload/bip/strategie_ plany_programy/Polityka_Ekologiczna_Panstwa/ Polityka_Ekologiczna_Panstwa_2030.pdf.

Samuelson, Paul A., and William D. Nordhaus. 2012. Ekonomia. T. 2. Warszawa: Wydawnictwo Naukowe PWN.

Service Agency Communities in One World. 2013. Participatory budgeting worldwide - updated version. Bon: ENGAGEMENT GLOBAL gGmbH - Service für Entwicklungsinitiativen. Accessed February 15, 2021. http://www.service-eine-welt. de/en/images/text_material-3651.img.

Szczupaczyński, Jerzy. 2017. „Zarządzanie przez wartości." W Nowe idee zarzadzania publicznego. Wyzwania i dylematy, red. Ewa M. Marciniak, i Jerzy Szczupaczyński, 81-98. Warszawa: INP Wydział Nauk Politycznych i Studiów Międzynarodowych UW.

Varian, Hal R. 2002. Mikroekonomia. Kurs średni - ujęcie nowoczesne. Warszawa: Wydawnictwo Naukowe PWN. 